\title{
Diagnostic Significance of Haemogram Parameters and RBC Indices in Haemoglobin E Trait
}

\author{
*T Khondaker ${ }^{1}$, AKJ Ahmed ${ }^{2}$, SK Amin ${ }^{3}$
}

\begin{abstract}
Background: Hemoglobin E disease are the most common structural haemoglobinopathies, reaching its highest frequency in South East Asia and also prevalent in Bangladesh. There are very few data for effective screening of HB E trait. The aim of the study was to analyze hematological profile and RBC indices as a marker of screening for $\mathrm{Hb} \mathrm{E}$ trait.

Methodology: A cross sectional observational study was conducted among 150 subjects at Dhaka Shishu (Children) Hospital from December 2008 to November 2009. On the basis of Hb electrophoresis, all subjects were divided into three groups. Group I comprised of 50 subjects with $\mathrm{Hb} \mathrm{E}$ trait, group II comprised 51 subjects with $\beta$ thalassemia trait and Group III comprised of 49 normal subjects. Result of $\mathrm{RBC}$ indices and blood count were compared between $\mathrm{Hb} \mathrm{E}$ trait and normal study population.

Results: In group I the mean age was 29.53 years and the age range was 2-47 years. In group II the mean age was 30.31 years and the range was $1-55$ years. In group III the mean age was 21.81 years and the range was 1-52 years. The present study revealed the mean \pm SD haemoglobin level $(\mathrm{g} / \mathrm{dl})$ in group I (E trait) and group III (normal subjects) were 11.76 \pm 1.91 and $10.77 \pm 1.4$ respectively. Statistically no significant difference was found between these 2 groups $(\mathrm{P}>.05)$. The mean corpuscular volume (MCV) in mean \pm SD in group I and group III were $72.89 \pm 12.24 \mathrm{fl}$ and $77.35 \pm 10.27 \mathrm{fl}$ respectively. No statistical significance was found as $\mathrm{P}>0.05$. The mean corpuscular haemoglobin $(\mathrm{MCH})$ and mean corpuscular haemoglobin concentration (MCHC) in group I were $24.84 \pm 2.71 \mathrm{pg} \& 32.97 \pm 2.27 \mathrm{~g} / \mathrm{dl}$ and in group III were $28.28 \pm 2.71 \mathrm{pg} \& 32.97 \pm 2.38 \mathrm{~g} / \mathrm{dl}$ respectively. There were no significant difference between group I and III regarding $\mathrm{MCH}$ and $\mathrm{MCHC}$. The mean $\mathrm{RBC}$ count in E trait and normal subject group were $5.01 \pm 71 \mathrm{million} / \mathrm{cmm}$ and $4.61 \pm 0.65 \mathrm{million} / \mathrm{cmm}$ respectively. There was no significant difference was found $\mathrm{P}>0.05$. Mean red cell distribution width (RDW) in group I and III were 14.32 \pm 2.34 and $14.83 \pm 1.28$ without any statistical difference $(\mathrm{P}>0.05)$
\end{abstract}

Conclusion: In our study there were no diagnostic significance of Blood count and RBC Indices for detection of $\mathrm{Hb} \mathrm{E}$ trait. More study should be conducted to find out reliable marker of screening for $\mathrm{Hb} \mathrm{E}$ carrier.

Key Words: Hb E Disease, Hb E Trait. B Thalassemia trait

\section{Introduction}

Hemoglobinopathies and thalassaemia are including South East Asia ${ }^{2}$. The hereditary disorder heterogeneous group of hereditary disorders of haemoglobin usually present as either a reduced prevalent worldwide ${ }^{1}$. They represent a major rate of production of one or more of the globin public health problem in many areas of the world chain (thalassaemia) nor those in which there is

${ }^{1}$ Dr Tarannum Khondaker, Junior Consultant, NICU, Anwer khan Modern Medical College \& Hospital

${ }^{2} \mathrm{Dr}$ Abul Kashem Jalaluddin Ahmed, General practitioner, Drayton Street Family Practice, Nanango, Australia

${ }^{3}$ Dr Syed Khairul Amin, Professor and Head, Department of paediatrics, Anwer khan Modern Medical College and Hospital

*Corresponding Author

Date of submission: 08.10.2016, Date of acceptance: 23.01.2017 
structural changes in a globin chain like $\mathrm{Hb} \mathrm{E}, \mathrm{Hb}$ $\mathrm{C}, \mathrm{Hb} \mathrm{D}$ etc $^{3}$. $\mathrm{Hb} \mathrm{E}$ is the second most prevalent $\mathrm{Hb}$ variant in the world and has a worldwide carrier of 53 million.4It is estimated that about 250 million people $(4.5 \%$ of the population) carry a potential pathological haemoglobinopathy gene and about $3,00,000$ infants are born with major haemoglobinopathies ${ }^{6}$. Haemoglobin E is the second most common variant haemoglobin worldwide and it is the hallmark of South East Asia and extends from Eastern part of India, Bangladesh, Burma, Laos, Thailand and Cambodia. It is estimatated that 30 million South East Asians are heterozygous of Haemoglobin $E^{7}$. It has been noted to be an important health problem in the Indian subcontinent and South east Asia. It has replaced B thalassemia as the most common thalassemia disorder in many regions. The frequency of $\mathrm{Hb} \mathrm{E}$ approaches $60 \%$ in many regions of Thailand, Laos and Cambodia. The World Health Organization (WHO) estimated that in Thailand at least 1,00,000 new cases of $\mathrm{Hb} \mathrm{E} \beta$ thalassemia are expected in the next few decades ${ }^{8}$.

There is no definite data regarding carriers of hereditary disorder existing in Bangladesh. A conservative World Health report has estimated that 3 percent (3.6 million) carriers of $\beta$ thalassemia and 4 percent( 4.8 million) are carriers of $\mathrm{Hb} \mathrm{E}$ in Bangladesh. More than two thousand thalassemic children are born every year in Bangladesh ${ }^{9}$. A study showed that carrier status of $\mathrm{Hb} \mathrm{E}$ is $6.1 \%$ and about $40 \%$ from tribal children of Bangladesh $^{10}$.

$\mathrm{Hb} \mathrm{E}$ is caused by a substitution of glutamic acid by lysine at position 26 of the $B$ globin chain ${ }^{11}$. Patient of $\mathrm{Hb} \mathrm{E}$ trait has no clinical significance. Patient may have mild microcytosis without anemia.

The impact of problem is that haemoglobin $\mathrm{E}$ carriers and homozygous $\mathrm{Hb} \mathrm{E}$ people can produce diseased off spring if they get married with $\beta$ thalassemia carriers. The $\mathrm{Hb} \mathrm{E} / \mathrm{B}$ thalassemia compound heterozygote is the most common abundant form of thalassemia disease in Bangladesh ${ }^{10}$. The compound heterozygote state of $\mathrm{Hb}$ E $\mathrm{B}$ thalassemia results in a variable phenotype ranging from a complete lack of symptoms to transfusion dependency ${ }^{13,14}$. Approximately one half of the patients are phenotypically similar to patients with thalassemia major who require regular transfusion therapy and the other half resembles thalassemia Intermedia ${ }^{15}$. Transfusion dependent severe $E$ B thalassemia patients need regular blood transfusion, iron chelation therapy and treatment of various complications which are very expensive. In India,the cost of treatment of thalassemic child amounts to Rs 90,000 to 100,000 annually at around 3 years of age which increases as the child grows. As a poor country, it is not possible for us to bear expense of treatment of thalassemia patient. The only available curative treatment of thalassemia is bone marrow transplantation which is far beyond our reach. Majority of the patient die due to lack of treatment ${ }^{16}$. The present management gives a probable life expectancy beyond third or fourth decade. The quality of life of patients and burden of the families due to treatment represents for public health service clearly underline the fundamental aspects of prevention rather than treatment ${ }^{17,18}$. Prevention which includes population education, mass screening, genetic counseling and prenatal diagnosis is the only effective way to cope with such disease ${ }^{16,18}$. For effective genetic counseling the population at risk needs to be identified. The aim of the carrier screening is to identify carriers of haemoglobin disorders in order to assses the risk of couple having a severly affected child and to provide information on the options available to avoid such an eventuality ${ }^{19}$. NESTROFT ( Naked Eye Single Tube Red cell Osmotic Fragility Test) is found to be very useful for detecting beta thalassemia trait ${ }^{20}$. Beta thalassemia trait can also be screened by using RBC indices where $\mathrm{MCV}$ and $\mathrm{MCH}$ values are low with high $\mathrm{RBC}$ count ${ }^{21}$. Hb E heterozygote are clinically well. Screening of $\mathrm{Hb} \mathrm{E}$ carrier is equally necessary as they combine with $\mathrm{B}$ thalassemia trait to cause $\mathrm{Hb}$ $\mathrm{E} B$ thalassemia which is the most common thalassemia syndrome in Bangladesh. There are doubtful role of blood count and RBC indices in detecting $\mathrm{Hb} \mathrm{E}$ trait. The false negetive result with $\mathrm{MCV}$ and $\mathrm{MCH}$ for screening is unacceptable especially in a population where there is significant high prevalence of $\mathrm{Hb} \mathrm{E}^{22}$. The only screening as well as confirmatory test for detection of $\mathrm{Hb} \mathrm{E}$ trait is $\mathrm{Hb} \mathrm{E}$ estimation by $\mathrm{Hb}$ Electrophoresis which 
needs skilled personnel and require sophisticated equipments. For countries with limited resources, mass screening can be conducted using cheaper and a less complex methods ${ }^{23}$. There are no study in our country which can analyze the diagnostic significance of Blood count and RBC indices in detecting $\mathrm{Hb} \mathrm{E}$ carrier state. The present study was carried out to see the role of Blood count and RBC indices as a marker of screening for $\mathrm{Hb} \mathrm{E}$ trait.

\section{Methodology}

This hospital based cross sectional study was carried out at Dhaka Shishu (Children)Hospital from December 2008 to November 2009. A total number of 150 subjects were selected who were older than

1 year,not suffering from acute infections and without $\beta$ thalassemia major or $\mathrm{Hb} \mathrm{E} \beta$ thalassemia attending Dhaka Shishu Hospital Thalassemia Center were tested for haemoglobin, red cell count, red cell indices, peripheral blood film and haemoglobin electrophoresis. On the basis of $\mathrm{Hb}$ electrophoresis, all subjects were divided into three groups Group I comprised of 50 subjects with $\mathrm{Hb} \mathrm{E}$ trait, Group II comprised 51 subjects with $\beta$ thalassemia trait and Group III comprised of 49 normal subjects. $\mathrm{Hb} \mathrm{E}$ traits were detected by $\mathrm{Hb}$ electrophoresis when $\mathrm{Hb} \mathrm{E}$ level was found between $20 \%$ to $35 \%$. 49 subjects were detected normal by electrophoresis report and rest of 51 subjects were found to have B thalassemia trait. Among the study population, blood film, RBC indices and blood count were compared between $\mathrm{Hb} \mathrm{E}$ trait and normal study population. Data were analysed by SPSS programme.

\section{Results}

Table I: Age distribution among the study population $(\mathrm{n}=150)$

\begin{tabular}{lcc}
\hline Age (year) & Mean +- SD & Range \\
\hline E Trait $(\mathrm{n}=50)$ & $29.53+-10.70$ & $2-47$ \\
B Trait $(\mathrm{n}=51)$ & $30.31+-9.85$ & $1-55$ \\
Normal $(\mathrm{n}=49)$ & $21.81+-14.26$ & $1-52$ \\
\hline
\end{tabular}

In group I the mean age was 29.53 years and the age range was 2-47 years. In group II the mean age was 30.31 years and the range was 1-55 years. In group III the mean age was 21.81 years and the range was $1-52$ years.

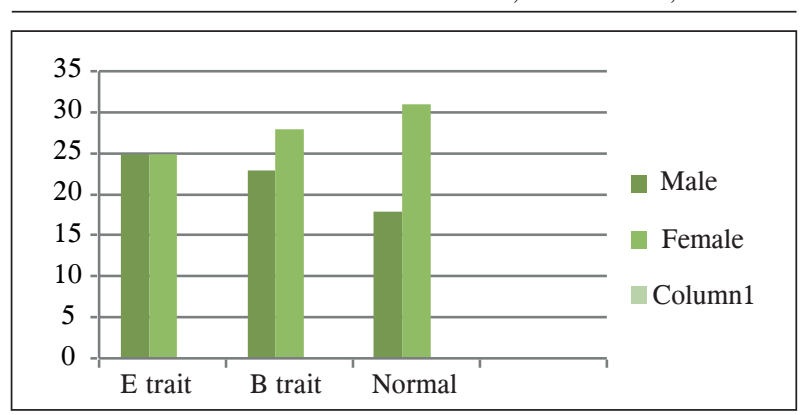

Figure 1: Sex distribution of study population $(n=150)$

In group 1, 25 male and 25 female $(n=50)$, in group II, 23 male and 28 female $(n=51)$, and in group III 18 male and 31 female $(n=49)$ subjects were included.

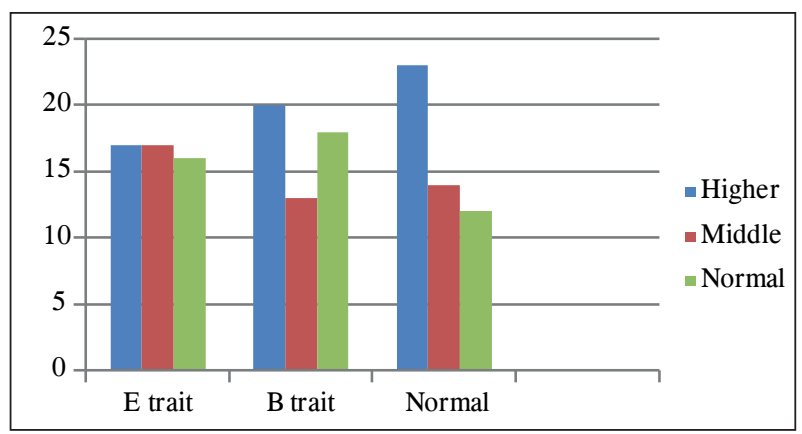

Fig -2 : Socio economic status of study population $(\mathrm{n}=150)$

In group I there is no significant variation of socio economic status but in group II and in group III the majority are from higher socio economic group. (fig 2)

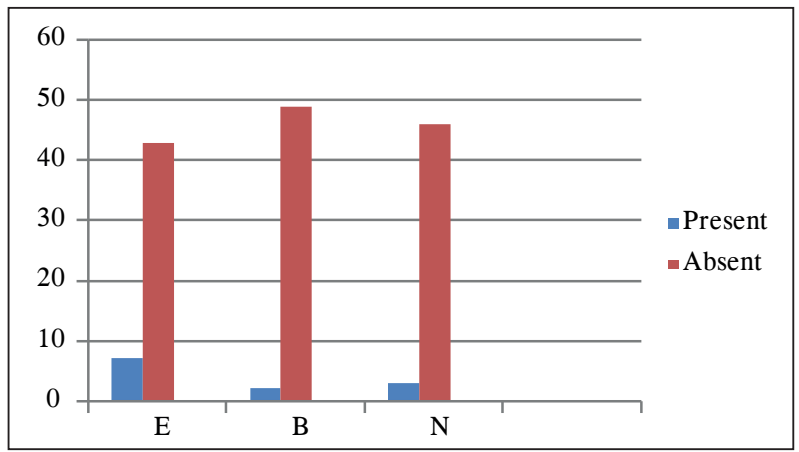

Fig 3 : Presence of consanguinity among the study population $(\mathrm{n}=150)$

In all the 3 groups majority of the study population were from non consanguineous parents but in Group I, seven of the subjects among the total 50 were from consanguineous parents. 
Comparison of Hematological parameter between $\mathrm{E}$ trait and normal subjects

Table 2 : Comparison of hematological parameter between $\mathrm{Hb} \mathrm{E}$ trait and normal subjects

\begin{tabular}{lllc}
\hline $\begin{array}{l}\text { Hematological } \\
\text { Parameters (Mean) }\end{array}$ & Mean +-SD & P value \\
\hline $\mathrm{Hb} \%(\mathrm{gm} / \mathrm{dl})$ & Normal $(\mathrm{n}=49)$ & $10.77+-14$ & 0.17 \\
& E trait $(\mathrm{n}=50)$ & $11.76+-1.91$ & \\
$\mathrm{MCV}(\mathrm{fl})$ & Normal $(\mathrm{n}=49)$ & $77.35+-10.27$ & 0.68 \\
& E Trait $(\mathrm{n}=50)$ & $72.89+-12.24$ & \\
$\mathrm{MCH}(\mathrm{pg})$ & Normal $(\mathrm{n}=49)$ & $28.28+-2.716$ & 0.33 \\
& E trait $(\mathrm{n}=50)$ & $24.84+-3.71$ & \\
$\mathrm{MCHC}(\mathrm{gm} / \mathrm{dl})$ & Normal $(\mathrm{n}=49)$ & $32.97+-2.38$ & 0.11 \\
& E trait $(\mathrm{n}=50)$ & $3282+-2.27$ & \\
$\mathrm{RBC} \mathrm{Count}$ & Normal $(\mathrm{n}=49)$ & $4.61+-.65$ & 0.87 \\
$(\mathrm{million} / \mathrm{cmm})$ & E trait $(\mathrm{n}=50)$ & $5.01+-.71$ & \\
& Normal $(\mathrm{n}=49)$ & $14.83+-1.28$ & 0.11 \\
$\mathrm{RDW}(\%)$ & E Trait $(\mathrm{n}=50)$ & $14.32+-2.34$ & \\
\hline
\end{tabular}

The present study revealed the mean $\pm S D$ haemoglobin level $(\mathrm{g} / \mathrm{dl})$ in group I (E trait) and group III(normal subjects) were $11.76 \pm 1.91$ and $10.77 \pm 1.4$ repectively. Statistically there was no significant difference was found between these 2 groups $(P>.05)$. The mean corpuscular volume $(M C V)$ in mean $\pm S D$ in group I and group III were $72.89 \pm 12.24 \mathrm{fl}$ and $77.35 \pm 10.27 \mathrm{fl}$ respectively. No statistical significance was found as $P>0.05$. The mean corpuscular haemoglobin $(\mathrm{MCH})$ and mean corpuscular haemoglobin concentration (MCHC) in group I were $24.84 \pm 2.71 \mathrm{pg} \& 32.97 \pm 2.27 \mathrm{~g} / \mathrm{dl}$ and in group III were $28.28 \pm 2.71 \mathrm{pg} \& 32.97 \pm 2.38 \mathrm{~g} / \mathrm{dl}$ respectively. There were no significant difference between group I and III regarding $\mathrm{MCH}$ and $\mathrm{MCHC}$.

The mean RBC count in E trait and normal subject group were $5.01 \pm 71 \mathrm{million} / \mathrm{cmm}$ and $4.61 \pm 0.65 \mathrm{million} / \mathrm{cmm}$ respectively. There was no significant difference was found.P $>0.05$. Mean red cell distribution width (RDW) in group I and III were $14.32 \pm 2.34$ and $14.83 \pm 1.28$ without any statistical difference $(P>0.05)$

\section{Discussion}

A number of studies have conducted by Fuchroen et $\mathrm{al}^{23}$, Wiwanikit et $\mathrm{al}^{24}$, Kannadit et $\mathrm{al}^{25}$ and Siripakorn et $\mathrm{al}^{26}$ and their sample size were 301, 213, 808 and 436 respectively to make an screening protocol for thalassemia patients in Thailand. In the present study in group I the mean age was 29.53 years and the age range was 2- 47 years. In group II the mean age was 21.81 years and the range was 152 years. The other study done by Fuchroen et al for simplified screening for thalassemia and $\mathrm{Hb} \mathrm{E}$ in rural communities the age range was $8-30$ years. ${ }^{23}$
In the present study in all 3 groups majority of the study population were from non consanguineous parents. Regarding socio economic status in group I there is no significant variation of socio economic condition but in group II and in group III the majority of the subjects are from higher socioeconomic group. It indicates that Dhaka Shishu (Children) Hospital Thalassemia Centre is creating awareness among all groups of people having thalassemia syndrome from different economic background. The other studies which have already mentioned earlier did not show anything about consanguinity and socio-economic status.

The present study revealed that the mean \pm SD haemoglobin level $\mathrm{g} / \mathrm{dl}$ in Group $\mathrm{I}(\mathrm{E}$ trait) and group III

(normal subjects) were $11.76 \pm 1.91$ and $10.77 \pm 1.4$ respectively. Statistically there was no significant difference was found between there 2 groups. Similar results were obtained by Fucharoen et al, who found normal haemoglobin level in both groups. $^{23}$

The mean corpuscular volume (MCV), mean corpuscular haemoglobin( $\mathrm{MCH})$ and mean corpuscular haemoglobin concentration $(\mathrm{MCHC})$ in mean $( \pm \mathrm{SD})$ for group I was $72.89 \pm 12.24$, $24.84 \pm 3.71 \mathrm{pg}$ and $32.82 \pm 2.27 \mathrm{~g} / \mathrm{dl}$ respectively and for group III were $77.35 \pm 10.27 \mathrm{fl}, 28.28 \pm$ $2.71 \mathrm{pg} \& 32.97 \pm 2.38 \mathrm{~g} / \mathrm{dl}$ respectively. No statistical significance was found regarding all parameters $(\mathrm{p}>0.05)$. $\mathrm{MCV}, \mathrm{MCH}$ and $\mathrm{MCHC}$ in $\mathrm{E}$ trait group were closer to normal subjects. Similar results were obtained by Fucharoen et al. ${ }^{23}$ Other study done by Sanchaisuriya et al 22 showed MCV and $\mathrm{MCH}$ were normal in $\mathrm{E}$ trait and they may give false negetive result for screening of $\mathrm{E}$ trait if $\mathrm{RBC}$ indices are considered as screening method.

The present study showed that RBC count in E trait and normal subject group were $5.01 \pm 0.71$ million $/ \mathrm{cmm}$ and $4.61 \pm 0.65$ million $/ \mathrm{cmm}$ respectively. But there was no significant difference was found $\mathrm{P}>0.05$. Mean red cell distribution width ( RDW) in group I and III were $14.32 \pm 2.34$ and $14.83 \pm 1.28$. That was also not statistically significant $\mathrm{P}>0.05$. The similar result was obtained by Fucharoen et al23 that showed no significant 
difference of RDW in different subjects who had different type of haemoglobin disorder. Many haemoglobin $\mathrm{E}$ carriers will be missed when these cut off values are used.

\section{Conclusion}

The frequency of $\mathrm{Hb} \mathrm{E}$ diasese is increasing day by day, though there is no effective prevention or screening program for the disease in Bangladesh. Many countries like Mediterranean and Western countries take initiatives to prevent this disease by antenatal diagnosis, screening, carrier detection and genetic counseling. Bangladesh needs such type of effective program to combat this deadly disease. The confirmatory tests needed for diagnosis of $\mathrm{E}$ trait are closely, laborious and time consuming. Mass screening methods should be identified to reduce the mortality and morbidity due to Thalassemia. However our study has some limitations like short duration and small sample size. Further studies on this issue should be conducted to establish a effective screening method for detection of $\mathrm{Hb} \mathrm{E}$ carrier.

\section{Conflict of interest}

We have no conflict of interest

\section{Reference}

1. LeCrone CN, Detter JC, Screening for haemoglobinopathies, Journal of Medical Technology 1985; 2: 285-95

2. Weatherall DJ, Clegg JB, Inherited haemoglobin disorders: an increasing global health problem. Bull World Health Organ 2001; 79: 704-12

3. Michael R, DeBaun, Vichinsky E. Haemoglobinopathies. In: Kleigman RM, Behrman RE, Jensen HB,Stanton BF, editors. Nelson Textbook of pediatrics.18th ed.New Delhi: Thompson Press; 2008: p2025-33

4. Weatherall DJ. Genetic disorders of haemoglobin. In: Hoffbrand AV, Lewis MS, Edward GD, editors. Postgraduate hematology. $4^{\text {th }}$ ed. Oxford: Oxford University Press; 1999: p 91119
5. Angastiniotis $\mathrm{M}$, Modell $\mathrm{B}$, Englezos $\mathrm{P}$, Boulyjenkov V. Prevention and control of haemoglobinopathies. Bulletin of the World Health Organization 1995: 73: 375-86.

6. Gibbons R, Higgs DR, Olivieri NF, Wood WG. The thalassemia in association with structural haemoglobin variants. In: Weatherall DJ, Clegg JB, editors. The thalassemia syndrome. $4^{\text {th }}$ Ed. Oxford, United kingdom: Blackwell Science; 2001: p 393-449.

7. Angastiniotis M, Eleftheriou A, Synodinos JA, Old J, Petrou M, Angastiniotis M, editors. Prevention of thalassemia and other haemooglobin disorders. Vol.1. Nicosia: Thalassemia International Federation Publication, 2003: p 10-23.

8. Old JM, Olivieri NF, Thien SL. Avoidance and population control. In: Weatherll DJ, Clegg JB, editors. The Thalassemia Syndromes $4^{\text {th }}$ ed. United Kingdom: Backwell Science; 2001: p 597-629.

9. Khan W A. Thalassemia in Bangaladesh. DS (Child) HJ 1999; 15: 42-44.

10. Khan WA, Banu B,Amin SK. Prevalence of Beta Thalassemia trait and $\mathrm{Hb} \mathrm{E}$ trait in Bangladesh school children and health burden of thalassemia in our population. DS (Child) HJ 2005; 21: 1-7

11. Firkin F, Chesterman C,Penington D, Rush B editors. De Gruchy's clinical haematology in medical practise. 5th ed. Oxford: Blackwell Science Ltd; 1989: p.137-171.

12. Frisher H,Bowman J. Haemoglobin E, an oxidatively unstable mutation.J Lab Clin Med 1975; 85: 531-539

13. Fucharoen S, Winichagoon P. Clinical and haematologic aspects of haemoglobin $\mathrm{E}$ beta thalassemia. Curr Opin Hematol 2000; 7: 106112

14. Fucharoen S, Ketvichit P, Pootrakul P, Siritanaraktul N, Piankijagum A, Wasi Clinical manifestation of beta thalassemia/haemoglobin E disease. J Pedi Hematol Oncol 2000; 22: 552-557 
15. Thomas S, Srivastava A, Jeyaseelan L.NESTROFT as a screening test for the detection of thalassemia and common haemoglobinopathies: an evaluation against a high performance liquid chromatographic method. Indian J Med Res1996; 104; 195-97

16. Manglani M,Lokeshwar MR,Vani VG. NESTROFT: An effective screening test for Beta thalassemia trait. Indian Paediatrics 1997; 34: $56-58$

17. Eleftheriou A. Health education. In: Galanello R ,Eleftheriou A, Synodinos JT, Old J, Petrou M, Angastiniotis $\mathrm{M}$, editors. In: Prevention of thalassemia and other haemoglobin disorders. Vol.1.Nicosia: Thalassemia International Federation Publication, 2003: p 1-9

18. World Health Organization. Hereditary disease programme. Guidelines for the control of haemoglobin disorder. Geneva: WHO; 1994

19. Galanello R. Screening and diagnosis for haemoglobin disorders. In: Galanello R, Eleftheriou A, Synodinos JT, Old J, Petrou M, Angastiniotis $\mathrm{M}$, editors. Prevention of thalassemias and other haemoglobin disorders. Vol 1. Nicosia: Thalassemia International Federation publication, 2003: p 34-60

20. Begum J A, Amin S K, Khan WA,Banu B, Selimuzzaman M, Sharmin $S$ et al. Evaluation of Naked Eye Single Tube Red Cell Osmotic Fragility Test (NESTROFT) in detecting Beta thalassemia trait. DS (Child) HJ 2005; 21: 4448

21. Gwendolyn M, Clarke, Trefor N H. Laboratory investigation of Haemoglobinopathies and Thalassemias. Review and update clinical Chemistry. 2000; 46 8(B): 1284-89.
22. Sanchaisuriya K, Fuchroen G, Ratnasiri T, Sanchaisuriya $\mathrm{P}$, Changtrakul $\mathrm{Y}$ et al.

A reliable screening protocol for Thalassemia and Haemoglobinopathies in pregnancy. American Journal of clinical Pathology 2005; 123: 113-118.

23. Fucharoen G, Sanchaisuriya K, Sae- Ung N, Dangwibul S, Fucharoen S.A Simplified Screening Strategy for Thalassemia and Haemoglobin E in Rural Communities in South East Asia. Bulletin of the World Health Organization 2004; 82: 364-72

24. Wiwanitkit V, Suwansaksri J, Paritpokee N. Combined one tube osmotic fragility (OF) test and dichlorophenol-indolphenol (DCIP) test screening for haemoglobin disorders, an experience in 213 Thai pregment women. Clin Lab 2002; 48: 525-28

25. Prayongratana K, Polprasert C, Raungrongmorakat K, Tatone K, Santiwatanakul S. Low cost combination of DCIP and MCV was better than that of DCIP and OF in the screening for Haemoglobin E.J of Med. Association of Thailand. 2008; 91; 234-240

26. Sangkitporn S, Sangoni A, Supangwiput O.Validation of Osmotic Fragility test and Dichlorophenol Indophenol Precipitation Test for screening of Thalassemia and $\mathrm{Hb} \mathrm{E}$. Southeast Asian J of Trop Med and Public Health 2005; 36:1538-42

27. Chappel L, Hariu A,Phelan L,Bain BJ. Reassessment of a simple chemical method using DCIP for screening of $\mathrm{Hb} \mathrm{E}$, J. clin. Pathol 2006; 59: 74-76. 